\title{
Proceeding
}

Supplementary Issue: Spring Conferences of Sports Science. Costa Blanca Sports Science Events, 14-15 June 2019. Alicante, Spain.

\section{Survey on exercise and sport sciences in Italy}

\author{
GAETANO RAIOLA \\ Department of Human, Philosophical and Education Sciences, University of Salerno, Italy
}

\begin{abstract}
In Italy, motor and sports sciences have been in the academy since 2000 following the reform of the higher institutes of physical education, ISEF. Subsequently, with the implementation of the Bologna process in 2011, the first three-year degree courses and the first professors divided into motor sciences and sports sciences were born. After almost twenty years of development they are within the academy like other scientific knowledge. The study focuses on the numerical consistency of degree courses and professors and the evolutionary trends between them to observe the variations. To aim the correlations between the different categories of variables: three-year and master's degree courses, professors and professors of physical education and sports sciences. The method is the archive search of official data in the ministerial database and the statistical analysis of them. The results show a significant correlation between the variables examined in relation to time, demonstration of a progressive development; moreover the correlations between all the examined variables are significant, further demonstration of a gradual development. It would be further useful to know the trends in the number of students and the trends of the degree courses and professors to check if there are significant correlations between them also for these trends. Keywords: Professors M-EDF/01 and M-EDF/02; Bachelor's degrees; Master's degrees.
\end{abstract}

\section{Cite this article as:}

Raiola, G. (2019). Survey on exercise and sport sciences in Italy. Journal of Human Sport and Exercise, 14(4proc), S1163-S1168. doi:https://doi.org/10.14198/ihse.2019.14.Proc4.81

Corresponding author. Department of Human, Philosophical and Education Sciences, University of Salerno, Italy. http://orcid.org/0000-0002-7659-1674

E-mail: graiola@unisa.it

Supplementary Issue: Spring Conferences of Sports Science. Costa Blanca Sports Science Events, 14-15 June 2019. Alicante, Spain.

JOURNAL OF HUMAN SPORT \& EXERCISE ISSN 1988-5202

(c) Faculty of Education. University of Alicante

doi:10.14198/jhse.2019.14.Proc4.81 


\section{INTRODUCTION}

In Italy, motor and sports sciences have been in the academy since 2000 following the reform of the higher institutes of physical education, ISEF (D'Isanto, 2019). Subsequently, with the implementation of the Bologna process in 2011, the first three-year degree courses and the professors are divided by physical education sciences academic disciplines and sports sciences one (D'Elia 2019, D'Elia et al, 2019). After almost twenty years of development they are within the academy like other scientific knowledge. The study focuses on the numerical consistency of degree courses (Sanseviero et al, 2019ab) and professors and the evolutionary trends between them to observe the variations. To aim the correlations between the different categories of variables: three-year and master's degree courses, professors and professors of physical education and sports sciences.

\section{METHODS}

The method is the archive search of official data in the ministerial database and the statistical analysis of them. The correlations between all the variables considered were calculated using the Pearson correlation coefficient. Statistical analysis was performed using SPSS 22.0 (SPSS Inc., Chicago, IL, USA). For all the performed analyses, a $p$-value $<0.05$ was considered significant.

\section{RESULTS}

In the table 1 it is shown the whole data where is the complex data in aggregated form and disaggregated one. The data were collected and grouped according to 11 variables and distributed over a period of 20 years.

In the figure 1 it is shown the trend over the years (from 2001/02 to 2019/20) in relation to the total number of the professors. Since 2006/07 there has been an exponential increase in the number of them, compared to previous years. Finally, in the table 2 are shown several correlations between considerate variables.

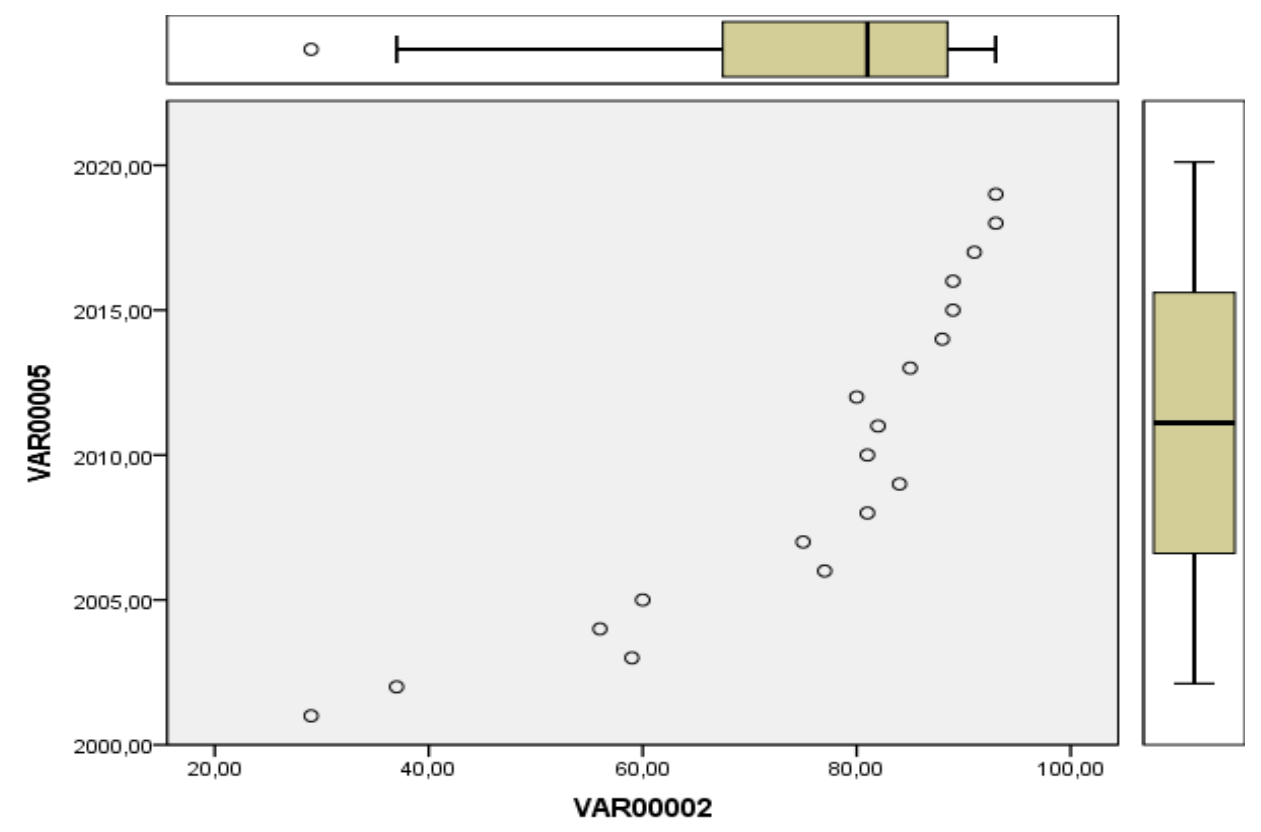

Figure 1. VAR05 $=$ Academic years and VAR02 $=$ Total number of the structured. 
Table 1. Complex data of degrees program and professor

\begin{tabular}{|c|c|c|c|c|c|c|c|c|c|}
\hline $\begin{array}{l}\text { Academic } \\
\text { year }\end{array}$ & Professors & $\begin{array}{l}\text { Degree } \\
\text { programs }\end{array}$ & $\begin{array}{l}\text { Professor of } \\
\text { Physical } \\
\text { activity M- } \\
\text { EDF/01 }\end{array}$ & $\begin{array}{l}\text { Professor of } \\
\text { sports } \\
\text { sciences M- } \\
\text { EDF/02 }\end{array}$ & $\begin{array}{l}\text { Bachelor's } \\
\text { degrees }\end{array}$ & $\begin{array}{l}\text { Master's } \\
\text { degrees }\end{array}$ & $\begin{array}{l}\text { Master's degrees' } \\
\text { program of Sport } \\
\text { management } 53 S \\
\text { and LM47 }\end{array}$ & $\begin{array}{l}\text { Master's } \\
\text { degrees } \\
\text { Adapted } \\
\text { physical } \\
\text { activity76S } \\
\text { and LM67 }\end{array}$ & $\begin{array}{l}\text { Master's } \\
\text { degree Sports } \\
\text { sciences } 75 S \\
\text { and LM68 }\end{array}$ \\
\hline 2001-02 & 0 & 29 & 0 & 0 & 29 & 0 & 0 & 0 & 0 \\
\hline $2002-03$ & 21 & 37 & 10 & 11 & 32 & 16 & 3 & 9 & 4 \\
\hline 2003-04 & 27 & 59 & 13 & 14 & 33 & 26 & 3 & 13 & 10 \\
\hline 2004-05 & 44 & 56 & 21 & 23 & 33 & 35 & 6 & 17 & 12 \\
\hline $2005-06$ & 76 & 60 & 35 & 41 & 36 & 36 & 7 & 17 & 12 \\
\hline $2006-07$ & 107 & 77 & 47 & 60 & 37 & 40 & 7 & 22 & 11 \\
\hline $2007-08$ & 113 & 75 & 61 & 52 & 37 & 40 & 6 & 22 & 12 \\
\hline${ }^{*} 2008-09$ & 128 & ${ }^{* *} 57+24=81$ & 73 & 55 & ${ }^{* *} 24+12=36$ & $* * 33+12=45$ & $* * 5+2=7$ & $* * 18+7=25$ & $* * 10+3=13$ \\
\hline${ }^{*} 2009-10$ & 134 & $* * 27+57=84$ & 76 & 58 & ${ }^{* *} 9+26=35$ & $* * 18+31=49$ & $* * 4+4=8$ & $* * 8+17=25$ & ${ }^{*} 6+10=16$ \\
\hline $2010-11$ & 140 & 81 & 73 & 67 & 32 & 49 & 7 & 26 & 16 \\
\hline $2011-12$ & 152 & 82 & 77 & 75 & 34 & 48 & 5 & 26 & 17 \\
\hline $2012-13$ & 162 & 80 & 78 & 84 & 34 & 46 & 4 & 26 & 16 \\
\hline 2013-14 & 166 & 85 & 78 & 88 & 35 & 50 & 5 & 27 & 18 \\
\hline 2014-15 & 164 & 88 & 79 & 85 & 36 & 52 & 5 & 29 & 18 \\
\hline $2015-16$ & 168 & 89 & 80 & 88 & 36 & 53 & 5 & 30 & 18 \\
\hline 2016-17 & 167 & 89 & 81 & 86 & 36 & 53 & 5 & 30 & 18 \\
\hline 2017-18 & 163 & 91 & 76 & 87 & 36 & 55 & 6 & 31 & 18 \\
\hline 2018-19 & 168 & 93 & 84 & 84 & 38 & 55 & 6 & 31 & 18 \\
\hline $2019-20$ & 170 & 93 & 87 & 83 & 38 & 55 & 6 & 31 & 18 \\
\hline
\end{tabular}

${ }^{\star}$ Transition years for specialized degrees and master's degrees. ${ }^{* *}$ Disaggregated data for bachelor's degrees type and master's degrees type and aggregates for both of them.

Table 2. Correlation among whole variables about professors and degree programs between 2001-2020

\begin{tabular}{|c|c|c|c|c|c|c|c|c|c|c|c|}
\hline \begin{tabular}{|l|} 
VAR01 \\
Structured total
\end{tabular} & & VAR01 & VAR02 & VAR03 & VAR04 & VAR06 & VAR07 & VAR08 & VAR09 & VAR010 & VAR011 \\
\hline \multirow{3}{*}{$\begin{array}{l}\text { VAR01 } \\
\text { Structured total }\end{array}$} & Pearson correlation & 1 & $.958^{* *}$ & $.988^{* *}$ & $.989^{* *}$ & $.679^{* \star}$ & $.941^{\star \star}$ & $.916^{* *}$ & $.514^{*}$ & $.963^{* *}$ & $.926^{* *}$ \\
\hline & Sign. (with two tails) & & .000 & .000 & .000 & .001 & .000 & .000 & .024 & .000 & .000 \\
\hline & $\mathrm{N}$ & 19 & 19 & 19 & 19 & 19 & 19 & 19 & 19 & 19 & 19 \\
\hline
\end{tabular}




\begin{tabular}{|c|c|c|c|c|c|c|c|c|c|c|c|}
\hline \multirow{3}{*}{$\begin{array}{l}\text { VAR02 } \\
\text { Total degree courses }\end{array}$} & Pearson correlation & $.958^{* *}$ & 1 & $.956^{* *}$ & $.939^{* *}$ & $.766^{* *}$ & $.976^{* *}$ & $.884^{* *}$ & $.628^{* *}$ & $.984^{* *}$ & $.951^{* *}$ \\
\hline & Sign. (with two tails) & .000 & & .000 & .000 & .000 & .000 & .000 & .004 & .000 & .000 \\
\hline & $\mathrm{N}$ & 19 & 19 & 19 & 19 & 19 & 19 & 19 & 19 & 19 & 19 \\
\hline \multirow{3}{*}{$\begin{array}{l}\text { VAR03 } \\
\text { M-EDF } 01 \\
\text { total }\end{array}$} & Pearson correlation & $.988^{* *}$ & $.956^{* *}$ & 1 & $.955^{\star *}$ & $.669^{* *}$ & $.935^{* *}$ & $.889^{* *}$ & $.553^{*}$ & $.953^{* *}$ & $.911^{* \star}$ \\
\hline & Sign. (with two tails) & .000 & .000 & & .000 & .002 & .000 & .000 & .014 & .000 & .000 \\
\hline & $\mathrm{N}$ & 19 & 19 & 19 & 19 & 19 & 19 & 19 & 19 & 19 & 19 \\
\hline \multirow{3}{*}{$\begin{array}{l}\text { VAR04 } \\
\text { M-EDF } 02 \\
\text { total }\end{array}$} & Pearson correlation & $.989^{* \star}$ & $.939^{* \star}$ & $.955^{* *}$ & 1 & $.673^{* *}$ & $.925^{* \star}$ & $.921^{* *}$ & $.464^{*}$ & $.950^{* *}$ & $.920^{*}$ \\
\hline & Sign. (with two tails) & .000 & .000 & .000 & & .002 & .000 & .000 & .046 & .000 & .000 \\
\hline & $\mathrm{N}$ & 19 & 19 & 19 & 19 & 19 & 19 & 19 & 19 & 19 & 19 \\
\hline \multirow{3}{*}{$\begin{array}{l}\text { VAR06 } \\
\text { 1st level degrees }\end{array}$} & Pearson correlation & $.679^{* *}$ & $.766^{* *}$ & $.669^{* *}$ & $.673^{* *}$ & 1 & $.752^{* *}$ & $.655^{\star *}$ & $.656^{* *}$ & $.758^{* *}$ & $.671^{* *}$ \\
\hline & Sign. (with two tails) & .001 & .000 & .002 & .002 & & .000 & .002 & .002 & .000 & .002 \\
\hline & $\mathrm{N}$ & 19 & 19 & 19 & 19 & 19 & 19 & 19 & 19 & 19 & 19 \\
\hline \multirow{3}{*}{$\begin{array}{l}\text { VAR07 } \\
\text { 2nd level degrees }\end{array}$} & Pearson correlation & $.941^{* \star}$ & $.976^{* *}$ & $.935^{* *}$ & $.925^{*}$ & $.752^{* *}$ & 1 & $.864^{* *}$ & $.701^{* *}$ & $.992^{* *}$ & $.980^{* *}$ \\
\hline & Sign. (with two tails) & .000 & .000 & .000 & .000 & .000 & & .000 & .001 & .000 & .000 \\
\hline & $\mathrm{N}$ & 19 & 19 & 19 & 19 & 19 & 19 & 19 & 19 & 19 & 19 \\
\hline \multirow{3}{*}{$\begin{array}{l}\text { VAR08 } \\
\text { Academic years }\end{array}$} & Pearson correlation & $.916^{* *}$ & $.884^{* *}$ & $.889^{* *}$ & $.921^{* *}$ & $.655^{\star *}$ & $.864^{* *}$ & 1 & .335 & $.903^{* *}$ & $.870^{* *}$ \\
\hline & Sign. (with two tails) & .000 & .000 & .000 & .000 & .002 & .000 & & .161 & .000 & .000 \\
\hline & $\mathrm{N}$ & 19 & 19 & 19 & 19 & 19 & 19 & 19 & 19 & 19 & 19 \\
\hline \multirow{3}{*}{$\begin{array}{l}\text { VAR09 } \\
53 S \\
\text { LM47 } \\
\end{array}$} & Pearson correlation & $.514^{*}$ & $.628^{* *}$ & $.553^{*}$ & $.464^{*}$ & $.656^{* *}$ & $.701^{* *}$ & .335 & 1 & $.636^{* *}$ & $.601^{* \star}$ \\
\hline & Sign. (with two tails) & .024 & .004 & .014 & .046 & .002 & .001 & .161 & & .003 & .007 \\
\hline & $\mathrm{N}$ & 19 & 19 & 19 & 19 & 19 & 19 & 19 & 19 & 19 & 19 \\
\hline \multirow{3}{*}{$\begin{array}{l}\text { VAR010 } \\
76 S \\
\text { LM75 }\end{array}$} & Pearson correlation & $.963^{* *}$ & $.984^{* \star}$ & $.953^{* *}$ & $.950^{* *}$ & $.758^{* *}$ & $.992^{* *}$ & $.903^{* *}$ & $.636^{* *}$ & 1 & $.966^{* *}$ \\
\hline & Sign. (with two tails) & .000 & .000 & .000 & .000 & .000 & .000 & .000 & .003 & & .000 \\
\hline & $\mathrm{N}$ & 19 & 19 & 19 & 19 & 19 & 19 & 19 & 19 & 19 & 19 \\
\hline \multirow{3}{*}{$\begin{array}{l}\text { VAR011 } \\
75 S \\
\text { LM76 }\end{array}$} & Pearson correlation & $.926^{* *}$ & $.951^{* *}$ & $.911^{* *}$ & $.920^{* *}$ & $.671^{* \star}$ & $.980^{* *}$ & $.870^{* *}$ & $.601^{* *}$ & $.966^{* *}$ & 1 \\
\hline & Sign. (with two tails) & .000 & .000 & .000 & .000 & .002 & .000 & .000 & .007 & .000 & \\
\hline & $\mathrm{N}$ & 19 & 19 & 19 & 19 & 19 & 19 & 19 & 19 & 19 & 19 \\
\hline
\end{tabular}

**. The correlation is significant at level 0.01 (two-tailed). * The correlation is significant at level 0.05 (two-tailed).

In the Table 2 there are Significant correlation and not Not significant correlation. 
The figure 1 shows the trend over the years (from 2001/02 to 2019/20) in relation to the total number of the professors. Since 2006/07 there has been an exponential increase in the number of them, compared to previous years.

The table 1 shows the whole data where is the complex data in aggregated form and disaggregated one.

The value of the Pearson correlation (Table 2) shows how much more is near to 1 and more it is a high correlation, for example 0.989 ; otherwise, how much more it is near to 0 , the more it is a lower correlation, for example 0.335 .

\section{DISCUSSION}

A large part of the variables are strongly correlated with each other, while the variables 1st level degrees and 53S LM47 only show a lower correlation with the other variables. This means that the variables 1 st level degrees and 53S LM47 do not follow the same development and trend of the other variables, over the period of time considered.

The total structured variable shows a fair correlation (0.514) with the LM47, with the 1st level Degrees a good correlation (0.679); while a strength correlation with the remaining variables: Total degree courses $(0.958)$; M-EDF 01 total (0.988); M-EDF 02 total (0.989); 2nd level degrees (0.941); Academic years (0.916); $76 \mathrm{~S}$ LM75 (0.963) and 75S LM76 (0.926).

The variable total degree courses shows a good correlation with the 1st level Degrees $(0.766)$ and the LM47 (0.628), while with the remaining variables a strength correlation (M-EDF 01 total (0.956); M-EDF 02 total (0.939); 2nd level degrees (0.976); Academic years (0.884); 76 S LM75 (0.984); 75 S LM76 (0.951).

The total M-EDF 01 variable shows a fair correlation (0.553) with the LM47, with the 1st level Degrees a good correlation (0.669) and a strength correlation with the remaining M-EDF 02 variables total (0.955); 2nd level degrees (0.935); Academic years (0.889); 76S LM75 (0.953) and 75S LM76 (0.911).

The total M-EDF 02 variable shows a fair correlation (0.463) with the variable LM47, with the 1st level degrees a good correlation (0.673) and a strength correlation with the remaining variables 2 nd level degrees $(0.925)$; Academic years (0.921); 76 S LM75 (0.950); 75 S LM76 (0.920).

The 1 st level Degree variable shows good correlations with the 2 nd level Degrees (0.752), Academic years (0.655), 53 S LM47 (0.656), 76S LM75 (0.758) and 75S LM76 (0.671); while it does not have a strength correlation with any of the variables.

The 2 nd level Degree variable shows a good correlation (0.701) with the LM47 variable and a strength correlation with the Academic years (0.864), 76S LM75 (0.992) and 75S LM76 (0.980) variables.

The variable Academic years shows a low correlation (0.335) with the variable LM47, while a strength correlation with the variables $76 S$ LM75 and 75S LM76.

The variable 53S LM47 shows a good correlation with the variables 76S LM75 (0.636) and 75S LM76 (0.601); finally, the variable 76S LM75 shows a strength correlation with the variable 75S LM76 (0.966). 


\section{CONCLUSION}

The results show a significant correlation between the variables examined in relation to time, demonstration of a progressive development; moreover the correlations between all the examined variables are significant, further demonstration of a gradual development. It would be further useful to know the trends in the number of students and the trends of the degree courses and professors to check if there are significant correlations between them also for these trends.

\section{REFERENCES}

D'Elia, F. (2019). The training of physical education teacher in primary school. Journal of Human Sport and Exercise, 14(1proc), S100-S104. https://doi.org/10.14198/hhse.2019.14.Proc1.12

D'Isanto, T. (2019) Physical and sport education between Italian academic system and European Research Council structure panel, Journal of Human Sport and Exercise, 14, pp. S66-S76. https://doi.org/10.14198/ihse.2019.14.proc1.08

Sanseviero, I., Cassese, F.P., Fonzo, E., Altavilla, G., D'elia, F. (2019a) Study on the master's degree in sciences of sports evaluation and sport for disabled at the University of Salerno, Italy, Journal of Human Sport and Exercise, 14 (Proc2), pp. S239-S244. https://doi.org/10.14198/ihse.2019.14.proc2.12 